\title{
Cassava Varieties Trichome Density Influence the Infestation of Vatiga illudens (Hemiptera: Tingidae)
}

\author{
Marcelo Augusto Pastório ${ }^{1}$, Adriano Thibes Hoshino ${ }^{2}$, Luciano Mendes de Oliveira ${ }^{2}$, Wilmar Ferreira Lima ${ }^{3}$, \\ Thiago Augusto Paes Fernandes ${ }^{2}$, Ayres de Oliveira Menezes Júnior ${ }^{2} \&$ Humberto Godoy Androcioli ${ }^{3}$ \\ ${ }^{1}$ Universidade Estadual do Oeste do Paraná, Marechal Cândido Rondon, Brazil \\ ${ }^{2}$ Universidade Estadual de Londrina, Londrina, Brazil \\ ${ }^{3}$ Instituto Agronômico do Paraná, Londrina, Brazil \\ Correspondence: Humberto Godoy Androcioli, Instituto Agronômico do Paraná, Londrina, PR, Brazil. Tel: \\ 55-43-3376-2298. E-mail: handrocioli@iapar.br
}

Received: July 11, 2019

doi:10.5539/jas.v11n17p319
Accepted: September 1, $2019 \quad$ Online Published: October 15, 2019

URL: https://doi.org/10.5539/jas.v11n17p319

The research is financed by Coordenação de Aperfeiçoamento de Pessoal de Nivel Superior (CAPES).

\begin{abstract}
The objective of this study was to evaluate the infestation of Vatiga illudens in cassava varieties and to correlate its infestation with the physical and morphological parameters of resistance. The experiments were conducted in the 2014/2015 and 2016/2017 seasons, out in a randomized complete block design with nine treatments and five replicates. Nymphs and adults of $V$. illudens were evaluated on the abaxial surface of 16 leaves of the middle third of the plant. The density of trichomes was quantified with the use of electron micrographs, and the roughness of the epicuticular wax was assigned to the leaves of the shoot and the apical third. The color components $L^{*}, a^{*}, b^{*}$, were measured with a portable digital colorimeter. The cultivars IAC 90 and Santa Helena demonstrated the smallest infestations in the 2014/2015 season and maintained low infestation in the 2016/2017 season. The varieties Baianinha, IAC 576-70 and Catarina-Branca, maintained high infestations in the both seasons. The density of trichomes of the middle third of the plants correlated negatively to the $V$. illudens infestation for the two seasons. The higher density on trichomes, negatively affects the infestation of $V$. illudens in cassava varieties, characterizing as a specific resistance factor to this species.
\end{abstract}

Keywords: lace bug, populational density, leaf morphology, colorimeter parameters

\section{Introduction}

Lace bugs are exclusively phytophagous insects (Guidoti et al., 2015), five species are found on the cassava (Froeschner, 1993; Bellotti, 2008), but Vatiga illudens (Drake, 1922) and Vatiga manihotae (Drake, 1922) are frequently observed and considered important pests (Bellotti et al., 1999; Fialho et al., 2009). The genus Vatiga feed by sucking the parenchyma cell's protoplasm, causing yellow spots, which in severe infestations can cause leaf fall, this results in low photosynthetic capacity (Bellotti et al., 2012) and reduced plant productivity (Fialho et al., 2009).

Damage caused by arthropods in cassava have diminished, through the understanding of bioecology, use of integrated pest management (Bellotti et al., 2012), and by using sources of resistance, which were identified and introduced in varieties of high yield (Bellotti, 2002; Vieira et al., 2011). Physical, chemical and morphological factors are considered sources of resistance against arthropod pests (Chalwe et al., 2015; Prado et al., 2016). The trichome density has frequently been reported as resistance factor of the cassava towards some thrips species, demonstrating a negative correlation between trichome density and presence these insects (Schoonhoven, 1974, Parsa et al., 2015).

Considering the socioeconomic characteristics of the farmers who cultivate cassava, enhancement programs should be focused in resistance varietal studies, considered the most adequate as it is practical, economical and environmentally correct (Bellotti et al., 2012), reducing the chemical insecticides application. The Brazilian cassava varieties have distinct physical and morphological characteristics, that can confer resistance towards the 
lace bug and help in the selection of materials in the enhancement programs. Thus, this study aimed to evaluate the $V$. illudens infestation in different cassava varieties, and correlate its infestation with physical and morphological factors of resistance.

\section{Materials and Methods}

\subsection{Study Location and Experimental Design}

The study was conducted in field conditions during the 2014/2015 and 2016/2017 seasons, in the city of Londrina ( $\left(23^{\circ} 36^{\prime} \mathrm{S} ; 51^{\circ} 16^{\prime} \mathrm{W} ; 610\right.$ m.a.s.l.) with a Humid subtropical climate (Cfa) as classified by Köppen. The median temperature and accumulated precipitation, between the plantation $(15 / 11 / 2014)$ and the last evaluation $(30 / 10 / 2015)$ for the first season, was $22.75{ }^{\circ} \mathrm{C}$ and $1928.9 \mathrm{~mm}$, respectively, and between the plantation $(12 / 07 / 2016)$ and the last evaluation $(17 / 05 / 2017)$ in the second season was $21.8^{\circ} \mathrm{C}$ and $1307.5 \mathrm{~mm}$ respectively.

The experiments were performed using the random block design, with nine treatments (IAPAR 19, IPR Upira, IPR União, IAC 576-70, IAC 14, IAC 90, Catarina-Branca, Santa Helena and Baianinha) and five repetitions.

Each experimental parcel was composed of 36 plants, distributed in an area of $36 \mathrm{~m}^{2}(6 \mathrm{~m}$ width $\times 6 \mathrm{~m}$ length), where six cassava lines were planted, containing six plants each, with a $0.80 \mathrm{~m}$ spacing between plants and 0.90 $\mathrm{m}$ between the lines. The plantation began in the first fortnight of November 2014, for the first season, and in the first fortnight of July 2016, for the second season.

\subsection{Evaluation of Vatiga illudens Infestation on Cassava Leaves}

During the 2014/2015 season, the evaluations began on the 12/02/2015, extending to the 30/10/2015, where 11 evaluations were conducted. In the second season, the evaluations began at the 24/11/2016 and were concluded in the 17/05/2017, totaling 20 evaluations this year. Every survey was performed in the four central lines of each parcel, excluding the first and last plant of each line.

The evaluations consisted in the direct counting of $V$. illudens (nymphs and adults) present in four randomly selected plants. On each plant, the individuals present on the abaxial surface of four leaves were recorded, totaling 16 leaves per parcel. Each chosen leaf was positioned in one cardinal direction (north, south, east and west).

\subsection{Gathering of the Cassava Leaves and Material Preperation for Microscopic Reading}

Leaves from the nine varieties were gathered 210 days after the plantation (ATP), to proceed with the quantification of the number of trichomes present in each variety, and the characterization of the leaves epicuticular wax's rugosity. The harvest happened before the varieties flowering, following the procedure used by Schoonhoven (1974).

The block showed no effect over the varieties' trichome density in a preliminary test, so one repetition for each treatment was adopted, collecting one leaf from the medium third of each variety. After the gathering, the material was herbalised, using a drying kiln, without forced air circulation at $60{ }^{\circ} \mathrm{C}$, for a period of $72 \mathrm{~h}$, thus allowing a complete dehydration.

\subsection{Cassava Leaves' Trichome Quantification and Determination of the Epiderm Rugosity}

The herbalised material was sectioned and fixed to microscopic sample holders (stub), with its inferior face directed upwards, allowing the trichome quantification. The "stubs" were sprayed with gold to increase the samples' conductivity. For each sample a median section of the leaves' central lobe was examined, using an area of $4 \mathrm{~mm}^{2}(2 \mathrm{~mm} \times 2 \mathrm{~mm})$.

Trichome micrographs in the different cassava genotypes were obtained using a scanning electron microscope (SEM) (Phillips FEI, model Quanta 200), with a lense of 400× augmentation, these where square shaped, and covering an area of $0.032 \mu \mathrm{m}^{2}$ on the cassava leaf. Then each square was given a number, through a numeric lottery of six squares, the means were calculated. Ultimately, the trichome density observed was corrected to an area of $\mathrm{cm}^{2}$.

Utilizing the micrographs, the leaves' epidermal rugosity was determined through a score giving between 1 and 3 , in which: 1 = no rugosity; 2 = little rugosity; 3 = high rugosity, by three different evaluators, thus the means of the three scores were used as the final value for the morphological characterization.

\subsection{Determination of the Colorimeter Parameters}

A Konica Minolta ${ }^{\circledR}$ portable colorimeter, model Chroma Meter CR-400, CIELAB color system, calibrated to the $L^{*}, a^{*}, b^{*}$ scale, as this scale consistently correlates color values with visual perception of the human eye (Ohta \& Robertson, 2006), it was used to measure the parameters $L^{*}$ (Brightness), $a^{*}$ (Hue), and $b^{*}$ (Saturation), for the 
nine studied varieties.

The measurements were carried out on the field, a black colored board was used to support the leaf and to prevent the influence of reflected sunlight. The median section of the central lobe on the adaxial surface of five cassava leaves from each parcel was analized ( $\mathrm{n}=25$ per cassava variety).

\subsection{Statistical Analysis}

The results were submitted to a normality test and a homoscedasticity analysis, thus allowing the application of a variance analysis (ANOVA). The means' multiple comparisons were performed using the Skott-Knott test at 5\% probability.

Lastly, the mean of the lacebug infestation was correlated with the density of trichomes present on the plant's middle third leaves, the epicuticular wax roughness and the colorimetric parameters $L^{*}, a^{*}$, and $b^{*}$. Using the Pearson Correlation test (r). For both analyses, the result was deemed significant when $\mathrm{p} \leq 0.05$.

\section{Results and Discussion}

The varieties IAC 90 with 0.13 and Saint Helena with 0.27 lacebugs per leaf had the lowest density of $V$. illudens in the first season. For the 2016/2017 season, these varieties had again the lowest pest population, presenting 0.19 and 0.23 lacebugs per leaf, respectively, differing statistically from the IAPAR 19, IAC 576-70, Catarina-Branca and Baianinha varieties (Table 1).

Table 1. Median density of Vatiga illudens per leaf, in nine cassava varieties, Londrina, Paraná, seasons $2014 / 2015$ and 2016/2017

\begin{tabular}{|c|c|c|c|c|c|c|}
\hline \multirow{2}{*}{ Treatments } & \multicolumn{4}{|c|}{ Vatiga illudens } & \multirow{2}{*}{\multicolumn{2}{|c|}{$\begin{array}{l}\text { Trichomes } \\
\text { Medium Third }\end{array}$}} \\
\hline & \multicolumn{2}{|c|}{$2014 / 2015$} & \multicolumn{2}{|c|}{$2016 / 2017$} & & \\
\hline IAPAR 19 & $0.77^{*}$ & $\mathrm{c}$ & 0.34 & $\mathrm{~b}$ & $133.35 \pm 133.35$ & $\mathrm{~b}$ \\
\hline IPR Upira & 0.53 & $\mathrm{~b}$ & 0.23 & $\mathrm{a}$ & $4000.6 \pm 832.80$ & $\mathrm{a}$ \\
\hline IPR União & 0.45 & $\mathrm{~b}$ & 0.20 & $\mathrm{a}$ & $3067.16 \pm 480.82$ & $\mathrm{a}$ \\
\hline IAC 576-70 & 1.02 & $\mathrm{~d}$ & 0.34 & $\mathrm{~b}$ & $1333.55 \pm 480.82$ & $\mathrm{~b}$ \\
\hline IAC 14 & 0.97 & $\mathrm{~d}$ & 0.25 & $\mathrm{a}$ & $0.00 \pm 0.00$ & $\mathrm{~b}$ \\
\hline IAC 90 & 0.13 & $\mathrm{a}$ & 0.19 & $\mathrm{a}$ & $4800.77 \pm 832.80$ & $\mathrm{a}$ \\
\hline Catarina-Branca & 1.01 & $\mathrm{~d}$ & 0.38 & $\mathrm{~b}$ & $133.35 \pm 133.35$ & $\mathrm{~b}$ \\
\hline Santa-Helena & 0.27 & $\mathrm{a}$ & 0.23 & $\mathrm{a}$ & $1066.84 \pm 133.35$ & $\mathrm{~b}$ \\
\hline Baianinha & 1.09 & $\mathrm{~d}$ & 0.37 & $\mathrm{~b}$ & $533.42 \pm 266.71$ & $\mathrm{~b}$ \\
\hline GL & \multicolumn{2}{|l|}{32} & \multicolumn{2}{|l|}{32} & \multicolumn{2}{|l|}{18} \\
\hline CV (\%) & \multicolumn{2}{|c|}{24.93} & \multicolumn{2}{|c|}{27.48} & \multicolumn{2}{|l|}{48.45} \\
\hline $\mathrm{p}$ & \multicolumn{2}{|c|}{0.0024} & \multicolumn{2}{|c|}{0.0019} & \multicolumn{2}{|l|}{0.0001} \\
\hline
\end{tabular}

Note. ${ }^{*}$ Averages followed by the same letter in the column do not differ by Scott-Knott test at 5\% probability.

The varieties Baianinha, Catarina-Branca and IAC 576-70 (1.09, 1.01, 1.02 lace bugs per leaf, respectively), composed in the first year the group with the highest infestation, remaining in the second year with the highest infestation, with $0.37,0.38$ and 0.34 lace bugs, respectively. The IAPAR 19 and IAC 14 varieties, had an infestation which varied among the remaining varieties during the two seasons.

Oliveira et al. (2016), while evaluating the non-preference of $V$. illudens oviposition on cassava varieties, identified that IAC 90 and Santa Helena, were the varieties with a potential deterrent to the females' oviposition, whereas IAC 576-70 had a stimulating potential. These informations coincide with the largest and smallest infestations found in this study (Table 1). Although the authors did not evaluate the direct trichome presence as a factor related to the deterrent effect, they hypothesized this.

A significant negative correlation between lace bug and the trichome density of the varieties was found, where, $\mathrm{r}$ $=-0.7379 ; \mathrm{p}=0.0232$ and $\mathrm{r}=-0.7377 ; \mathrm{p}=0.0232$, for the $2014 / 2105$ and the $2016 / 2017$ seasons respectively (Figure 1). The lowest infestations of $V$. illudens were observed in the cultivars with the highest density of trichomes, indicating that this morphological factor may be related to the resistance of cassava varieties to this species. 

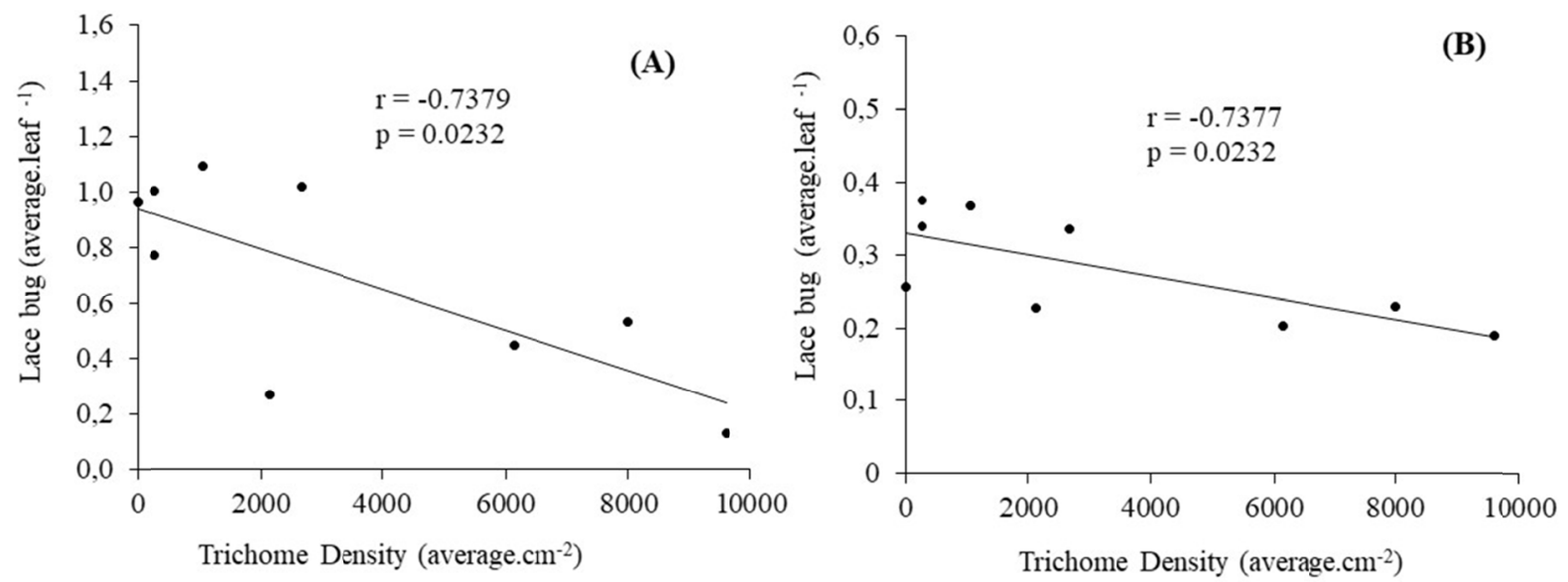

Fifure 1. Correlation (Pearson test, $\mathrm{p} \leq 0.05$ ) between the densities (average) of trichomes $\mathrm{cm}^{-2}$ in leaves of the middle third of cassava varieties with the infestation of Vatiga illudens, during 2014/2015 (A) and 2016/2017 (B) seasons, Londrina, Paraná

Wang et al. (1998), while evaluating the influence of the trichome density present on azalea (Rhododendron sp.) on the lace bug Stephanitis pyrioides (Scott, 1874) (Hemiptera: Tingidae), concluded that this parameter was not effective resistance mechanism, except for a single variety with a high density of trichomes, which presented resistance.

However, Schultz et al. (1987) negatively correlated the foliar pubescence and the nymph survival of Corythucha cydoniae (Fitch, 1861) (Hemiptera: Tingidae), verifying that on the leaf abaxial surface of the glabrous cultivars, there was a high nymphal survival rate. Cultivars affected there feeding, digestion and the females' oviposition, furthermore trichomes act as a physical barrier against locomotion and nymph adherence, exerting an antagonistic relationship. Lima et al. (2018) found that the species Aleurothrixus aepim (Goeldi) presents a similar behavior, in which higher densities of trichomes in cassava varieties, negatively affected the insect population.

Sucking insects, with a small size may demonstrate a reduced and unsatisfactory feeding in leaves with a high density of trichomes, due to the difficulty of the rostrum to reach the leaf parenchyma tissues (Webster, 1975; Norris \& Kogan, 1980), this alimentary difficulty can be a relevant factor for the $V$. illudens in cassava.

Even though there were differences of the $L^{*}, a^{*}$, and $b^{*}$ color parameters between the cassava cultivars, no correlation between these parameters and the populational density of $V$. illudens was obtained, thus this was not further deepened in this work. Likewise, there was no significant correlation between the density of lace bugs and the epicuticular wax's texture in the studied varieties.

Evaluating the infestation of $S$. pyrioides in azalea (Rhododendron spp.) cultivars, on different leaves' abaxial surface textures, Schultz (1993) did not verify a correlation between the acceptance of this bug with the leaf texture. In addition, Chappel and Robacker (2006), when studying S. pyrioides in azalea varieties, evidenced that the chemical composition seems to present a greater relevance, than the roughness of the epicuticular wax itself, in the host selection for this insect. These results could explain the lack of a significant correlation.

Although significant correlations for epicuticular wax rugosity and colorimetric parameters in relation to the infestation of $V$. illudens were not found, we should not exclude this possibility, evidencing that further studies should be conducted on other resistance parameters for cassava varieties on the lace bug $V$. illudens.

This study evidences that the high trichome density negatively affects the infestation of $V$. illudens in different cassava varieties.

\section{References}

Bellotti, A. C. (2002). Arthopods pests. In R. J. Hillocks, J. M. Thresh, \& A. C. Bellotti (Eds.), Cassava: Biology, production, and utilization (pp. 209-235). New York, CABI.

Bellotti, A. C. (2008). Cassava pests and their management. In J. L. Capinera (Ed.), Encyclopedia of entomology (pp. 764-794). Dordrecht, Springer. https://doi.org/10.1007/978-1-4020-6359-6_531 
Bellotti, A. C., Smith, L., \& Lapointe, S. (1999). Recent advances in cassava pest management. Annual Review of Entomology, 44, 343-370. https://doi.org/10.1146/annurev.ento.44.1.343

Bellotti, A., Campo, B. V. H., \& Hyman, G. (2012). Cassava production and pest management: Present and potential threats in a changing environment. Tropical Plant Biology, 5(1), 39-72. https://doi.org/10.1007/ s12042-011-9091-4

Chalwe, A., Melis, R., Shanahan, P., \& Chiona, M. (2015). Inheritance of resistance to cassava green mite and other useful agronomic traits in cassava grown in Zambia. Euphytica, 205, 103-119. https://doi.org/ 10.1007/s10681-015-1404-5

Chappell, M., \& Robacker, C. (2006). Leaf wax extracts of four deciduous azalea genotypes affect azalea lace bug (Stephanitispyrioides Scott) survival rates and behavior. Journal of the American Society for Horticultural Science, 131(2), 225-230. https://doi.org/10.21273/JASHS.131.2.225

Fialho, J., Vieira, E. A., Paula-Moraes, S. V., Silva, M. S., \& Junqueira, N. T. V. (2009). Danos causados por percevejo-de-renda na produção de parte aérea e raízes de mandioca. Scientia Agraria, 2, 151-155. https://doi.org/10.5380/rsa.v10i2.13587

Froeschner, R. C. (1993). The neotropical lace bugs of the genus Vatiga (Heteroptera: Tingidae), pests of cassava: New synonymies and key to species. Proceedings of Entomological Society, 95, 457-462. Retrieved from https://www.biodiversitylibrary.org/page/16151191\#page/483/mode/1up

Guidoti, M., Montemayor, S. I., \& Guilbert, E. (2015). Lace Bugs (Tingidae). In A. R. Panizzi, \& J. Grazia (Eds.), True Bugs (Heteroptera) of the Neotropics (395-419). Dordrecht, Springer. https://doi.org/10.1007/ 978-94-017-9861-7_14

Lima, W. H., Ringenberg, R., Fancelli, M., \& Silva Ledo, C. A. da. (2018). Resistance of Manihot esculenta and its intraspecific hybrids to the whitefly Aleurothrixus aepim (Hemiptera: Aleyrodidae). Pesquisa Agropecuária Brasileira, 53(8), 885-891. https://doi.org/10.1590/S0100-204X2018000800002

Norris, D. M., \& Kogan, M. (1980). Biochemical and morphological bases of resistance. In F. G. Maxwell, \& P. R. Jennings (Eds.), Breeding Plants Resistant to Insects (pp. 23-61). New York: John Wiley \& Sons.

Ohta, E. N., \& Robertson, A. R. (2006). Colorimetry: Fundamentals and applications. Chichester: John Wiley \& Sons.

Oliveira, H. N. de, Bellon, P. P., Souza Loureiro, E. de, \& Mota, T. A. (2016). Non-preference for oviposition cassava lace bug Vatiga illudens (Hemiptera: Tingidae) by Cassava Cultivars. Acta Biológica Colombiana, 21(2), 447-451. https://doi.org/10.15446/abc.v21n2.52021

Parsa, S., Medina, C., \& Rodríguez, V. (2015). Sources of pest resistance in cassava. Crop Protection, 68, $79-84$. https://doi.org/10.1016/j.cropro.2014.11.007

Prado, J. C. do, Peñaflor, M. F. G. V., Cia, E., Vieira, S. S., Silva, K. I., Carlini-Garcia, L. A., \& Lourenção, A. L. (2016). Resistance of cotton genotypes with different leaf colour and trichome density to Bemisia tabaci biotype B. Journal of Applied Entomology, 140, 405-413. https://doi.org/10.1111/jen.12274

Schoonhoven, A. Van. (1974). Resistance to thrips damage in cassava. Journal of Economic Entomology, 67, 728-730. https://doi.org/10.1093/jee/67.6.728

Schultz, P. B. (1993). Host plant acceptance of azalea lace bug (Heteroptera: Tingidae) for selected azalea cultivars. Journal of Entomological Science, 28, 230-235. https://doi.org/10.18474/0749-8004-28.2.230

Schultz, P. B., \& Coffelt, M. A. (1987). Oviposition and nymphal survival of the hawthorn lace bug (Hemiptera: Tingidae) on selected species of Cotoneaster (Rosaceae). Environmental Entomology, 16(2), 365-367. https://doi.org/10.1093/ee/16.2.365

Vieira, E. A., Fialho, J. D. F., Faleiro, F. G., Bellon, G., Fonseca, K. G. D., Carvalho, L. J. C. B., ... Denke, M. L. (2011). Characterization of sweet cassava accessions based on molecular, quantitative and qualitative data. Crop Breeding and Applied Biotechnology, 1(3), 232-240. https://doi.org/10.1590/S1984-703320110003 00005

Wang, Y., Robacker, C. D., \& Braman, S. K. (1998). Identification of resistance to azalea lace bug among deciduous azalea taxa. Journal of the American Society for Horticultural Science, 123(4), 592-597. https://doi.org/10.21273/JASHS.123.4.592 
Webster, J. A. (1975). Association of plant hairs and insect resistance: An annotated bibliography (p. 18). Michigan: Agricultural Research Service, US Department of Agriculture.

\section{Copyrights}

Copyright for this article is retained by the author(s), with first publication rights granted to the journal.

This is an open-access article distributed under the terms and conditions of the Creative Commons Attribution license (http://creativecommons.org/licenses/by/4.0/). 